\section{Epidural anaesthesia for labour and Caesarean section in a parturient with a single ventricle and transposition of the great arteries}

Jill Fong $M D, *$ Maurice Druzin $M D, \dagger$

Angela Antonacci Gimbel MD,* Jeffrey Fisher MD $\ddagger$
We describe a case of a 29-year-old parturient with a single ventricle and transposition of the great arteries who had lumbar epidural analgesialanaesthesia with a local anaesthetic for labour, emergency Caesarean section and posioperative pain. Her outcome and that of her baby was successful. The anaesthetic techniques used in other parturients with similar congenital cardiac anomalies are reviewed.

On décrit le cas d' une parturiente de 29 ans avec un ventricule unique et une transposition des gros vaisseaux qui a subi une anesthésie-analgésie épidurale lombaire avec un anesthésique local lors du travail, la césarienne d'urgence et l'analgésie postopératoire. L'issue chez la mère et le bébé se déroula sans complication. Les techniques anesthésiques utilisées chez $d$ 'autres parturientes avec des anomalies cardiaques congénitales similaires sont revues.

Pregnancy is rare in patients with a single ventricle and transposition of the great arteries (TGA). Single ventricle anomalies occur in only 1.5 per cent of patients with congenital heart disease, and 80 per cent of these patients have TGA with an equal incidence of dextro- and laevo-malpositions. ${ }^{1}$ Previously, pregnancy has been

\section{Key words}

ANAESTHESIA: obstetrical;

ANAESTHETIC TECHNIQUES: epidural;

HEART: congenital defects, single ventricle, transposition.

From the Departments of *Anesthesiology, †Obstetrics \& Gynecology, and ¥Medicine (Cardiology), The New York Hospital: Comell Medical Center, 525 East 68th Street, New York, NY 10021

Address correspondence to: Dr J. Fong, Department of Anesthesiology, The New York Hospital:Cornell Medical Center, 525 East 68th Street, New York, NY 10021. reported in only eight patients with a single ventricle with or without an associated TGA. ${ }^{2-9}$ According to Mangano, ${ }^{10}$ in parturients with cyanotic congenital heart disease avoidance of regional anaesthetic techniques may be wise because a decreased systemic vascular resistance and/or venous return may worsen the right-to-left-shunt This case presents the management of a parturient with a single ventricle and laevo-TGA. It is the first report of the use of lumbar epidural analgesia/anaesthesia with a local anaesthetic for labour, emergency Caesarean section, and postoperative pain.

\section{Case report}

A 29-yr-old patient was admitted for induction of labour after an amniocentesis indicated fetal maturity. Her complex past medical history included cyanotic congenital heart disease. Five years before this admission, cardiac catheterization revealed a single ventricle, laevoTGA, ventricular inversion, atrial septal defect, right atrioventricular valve atresia and mild subvalvular and valvular stenosis. Her single ventricle pressure was $120 / 10 \mathrm{mmHg}$ with a mean pulmonary artery pressure of $15-20 \mathrm{mmHg}$ and a normal pulmonary vascular resistance. Her haemoglobin oxygen saturations $\left(\mathrm{SaO}_{2}\right)$ were: inferior vena cava and right atrium 75 per cent, left atrium and ventricle 87 per cent, aorta 88 per cent and pulmonary artery 86 per cent. The ventricular ejection fraction was 28 per cent, and the haematocrit ( $\mathrm{Hct}$ ) was 56 per cent. The patient never had hypercyanotic spells or congestive heart failure.

Her obstetrical history included two spontaneous abortions six years before this admission and an uncomplicated successful pregnancy and vaginal delivery four years prior to admission. Throughout her previous pregnancy, the patient had a $\mathrm{Hct}$ of 55-60 per cent and an $\mathrm{SaO}_{2}$ of approximately 88 per cent. Labour was induced at 35 weeks gestation; the first stage lasted three hours with a fifteen-minute second stage. She delivered vaginally with 


\begin{tabular}{|c|c|c|c|c|c|}
\hline & \multirow[b]{2}{*}{ Preinduction } & \multirow[b]{2}{*}{ Epidural $\left(T_{10}\right)$} & \multirow[b]{2}{*}{ Epidural $\left(T_{5}\right)$} & \multicolumn{2}{|c|}{ Epidural bupivacainelfentanyl } \\
\hline & & & & $\begin{array}{l}\text { Early } \\
\text { postpartum }\end{array}$ & $\begin{array}{l}\text { Late } \\
\text { posipariıın }\end{array}$ \\
\hline Blood pressure (mmHg) & $128 / 82$ & $126 / 80$ & $122 / 78$ & $125 / 82$ & $132 / 80$ \\
\hline Pulse (beals $\cdot$ min $^{-1}$ ) & 72 & 80 & 80 & 78 & 68 \\
\hline CVP $(\mathrm{mmHg})$ & 2 & 3 & 4 & 4 & 6 \\
\hline $\mathrm{SpO}_{2}(\%)$ and $\left(\mathrm{FlO}_{2}\right)$ & $86(0.21)$ & $89(0.21)$ & $81(1.0)$ & $86(0.21)$ & $87(0.21)$ \\
\hline $\mathrm{ABG}\left(\mathrm{FlO}_{2}\right)$ & $7.44 / 27 / 46 / 19 / 84.6 \%(0.21)$ & & $7.50 / 20 / 48 / 17 / 88.4 \%(1.0)$ & & \\
\hline Respiratory rate (breaths ' $\mathrm{min}^{-1}$ ) & 16 & 16 & 18 & 16 & 16 \\
\hline
\end{tabular}

Abbreviations: haemoglobin oxygen saturation by pulse oximetry $\left(\mathrm{SpO}_{2}\right)$, Arterial blood gas $(\mathrm{ABG})$ listed as $\mathrm{pH} / \mathrm{PCO}_{2} / \mathrm{PO}_{2} / \mathrm{HCO}_{3}-1 \%$ sat, fraction of inspired oxygen $\left(\mathrm{F}_{1} \mathrm{O}_{2}\right)$.

the aid of a pudendal nerve block and local anaesthetic infiltration into the median episiotomy site. A $1740 \mathrm{~g}$ baby girl was delivered with Apgar scores of six and nine at one and five minutes, respectively. The neonate developed respiratory distress syndrome which resolved in two weeks.

In the seventeenth week of this current pregnancy, the patient had a retinal artery thromboembolism despite a stable $\mathrm{Hct}$ of $55-60$ per cent. Therefore, she was anticoagulated with subcutaneous heparin, and no other thromboembolic events occurred. An echocardiogram done at this time concurred with the previous cardiac catheterization.

On admission for elective induction of labour at 36 weeks gestation, the patient was $162 \mathrm{~cm}, 67 \mathrm{~kg}$ and had a New York Heart Association classification of $11 \mathrm{a}$. Her physical examination was remarkable for central cyanosis, marked digital clubbing, a grade IV/VI systolic ejection murmur heard maximally at the upper left sternal border radiating over the entire precordium into her neck, a grade IV/IV diastolic murmur and a gravid uterus. On room air, arterial blood gas analysis revealed a $\mathrm{PaO}_{2} 46$ $\mathrm{mmHg}$. Oxygen saturation by pulse oximetry $\left(\mathrm{SpO}_{2}\right)$ was 86 per cent, and the Hct was 55 per cent (Table I). Heparin was discontinued the evening before induction. One hour before induction, the partial thromboplastin time was slightly elevated at $40.1 \mathrm{sec}$ (normal 23-38 sec). All other coagulation studies were within normal limits. The electrocardiogram showed normal sinus rhythm, right ventricular hypertrophy, left axis deviation and intraventricular conduction delay. The chest $x$-ray was remarkable for a mildly convex upper left heart border, a near normal heart size and mildly increased pulmonary vascular markings.

The patient received gentamycin and vancomycin for prophylaxis against endocarditis because of her penicillin allergy. Monitoring was with a pulse oximeter, electrocardiogram, external tocodynamometer and fetal heart rate Doppler. In addition, a peripheral intravenous cathe- ter, radial arterial catheter and right cephalic vein central venous pressure (CVP) catheter were placed. Chest $x$-ray confirmed that the tip of the central venous catheter was positioned in the right atrium. The initial CVP was 2 $\mathrm{mmHg}$. During the placement of these catheters, the patient began to have spontaneous uterine contractions.

After hydration with $450 \mathrm{ml}$ Ringer's lactate, leading to a CVP of $4 \mathrm{mmHg}$, a lumbar epidural catheter was inserted, using preservative-free saline to test for the loss of resistance. ${ }^{11}$ The patient was placed in the supine position with left lateral tilt. Her CVP was maintained between 2-6 mmHg with intravenous Ringer's lactate. Bupivacaine 0.25 per cent was then injected through the epidural catheter in 2--3 ml aliquots over $15 \mathrm{~min}$ to a total dose of $20 \mathrm{mg}(8 \mathrm{ml})$. A tenth thoracic $\left(T_{10}\right)$ dermatome level of sensory blockade to pinprick and cold was achieved. After establishing adequate epidural analgesia, oxytocin was begun and infused at $\mathrm{l}-3$ milliunits $\cdot \mathrm{hr}^{-1}$. Two and a half hours after the initial dose, the patient required reinforcement of her epidural analgesia. She received a $6 \mathrm{ml}$ bolus of 0.25 per cent bupivacaine, and a continuous infusion of 0.125 per cent bupivacaine at 8 $\mathrm{ml} \cdot \mathrm{hr}^{-1}$ was begun which resulted in a sustained $\mathrm{T}_{10}$ dermatome level of sensory blockade to pinprick and cold, adequate analgesia and continued intact motor function.

After amniotomy was performed and clear fluid noted, an internal pressure transducer and fetal scalp electrode were placed. There were early fetal heart rate decelerations and mild variable decelerations over the next 30 minutes which culminated in a prolonged, seven-minute, fetal bradycardia. The fetal heart rate decreased from 130 to 70 beats $\cdot \mathrm{min}^{-1}$ This bradycardia persisted despite discontinuing the oxytocin, stable maternal haemodynamic variables and multiple maternal position changes. Therefore, an emergency Caesarean section was planned for fetal distress. While moving from the labour room to the operating room with continuous ECG, CVP, and mean arterial pressure monitoring, the patient received 15 
TABLE II Literature review

\begin{tabular}{|c|c|c|c|c|c|c|c|}
\hline Author (year) & Anomaly & $\begin{array}{l}\text { Maternal } \\
\text { age }\end{array}$ & $\begin{array}{l}\text { Mode of } \\
\text { delivery }\end{array}$ & Anaesthesia & $\begin{array}{l}\text { Pulmonary } \\
\text { hypertension }\end{array}$ & $\begin{array}{l}\text { Malernal } \\
\text { oucome }\end{array}$ & $\begin{array}{l}\text { Fetal oulcome } \\
\text { (weight) }\end{array}$ \\
\hline Mandel and Hirsh $(1963)^{2}$ & Single ventricle & $?$ & Vaginal & None & Yes & $\begin{array}{l}\text { Died I day } \\
\text { postpartum }\end{array}$ & $\begin{array}{l}\text { Died } 5 \text { months } \\
\text { gestation }(190 \mathrm{~g})\end{array}$ \\
\hline Yuzpe et al. (1976) & $\begin{array}{l}\text { Single ventricle, I-TGA, PDA, PS. } \\
\text { hypoplaslic aortic arch }\end{array}$ & 17 & Caesarean & General & No & Good & $\begin{array}{l}\text { Good } 40 \text {-week } \\
\text { gestation (2150g) }\end{array}$ \\
\hline Seeds and Cefalo $(1977)^{4}$ & $\begin{array}{l}\text { Single venuricle, single atrium, PS, } \\
\text { One AV valve, Potts shunt }\end{array}$ & 25 & $?$ & General & No & $\begin{array}{l}\text { Good; } \\
\text { hemoplysis }\end{array}$ & $?$ \\
\hline Ahmed er al. (1981) & $\begin{array}{l}\text { Single ventricle, PA band, Glenn } \\
\text { procedure }\end{array}$ & 19 & Vaginal & $\begin{array}{l}\text { Intrathecal morphine } \\
\text { and pudental block }\end{array}$ & No & Good & $\begin{array}{l}\text { Good: 36-week } \\
\text { gestation }(1700 \mathrm{~g})\end{array}$ \\
\hline \multirow[t]{2}{*}{ Leibbrandt et al. $(1982)^{6}$} & Single ventricle, I-TGA, PDA, mild AR & 24 & $\begin{array}{l}\text { Elective } \\
\text { Caesarean }\end{array}$ & Epidural & Yes & Good & $\begin{array}{l}\text { Good; } 40-\text { week } \\
\text { gestation }(1500 \mathrm{~g})\end{array}$ \\
\hline & & 29 & $\begin{array}{l}\text { Elective } \\
\text { Caesarean }\end{array}$ & Epidural & Yes & Good & $\begin{array}{l}\text { Good; } 37 \cdot \text { week } \\
\text { gestation }(1520 \mathrm{~g})\end{array}$ \\
\hline Stiller et al. (1984)? & Single ventricle, I-TGA, subvalvular PS & 23 & $\begin{array}{l}\text { Elective } \\
\text { Caesarean }\end{array}$ & General & No & Good & $\begin{array}{l}\text { Good; } 36-\text { week } \\
\text { gestation }(2353 \mathrm{~g})\end{array}$ \\
\hline Copel er al. $(1986)^{8}$ & Single ventricle, I-TGA, subval vular PS & 25 & Vaginal & $\begin{array}{l}\text { Intrathecal morphine } \\
\text { and pudental block }\end{array}$ & No & Good & $\begin{array}{l}\text { Good; } 36 \text {-week } \\
\text { gestation }(2880 \mathrm{~g})\end{array}$ \\
\hline Baumann et al. $(1987)^{9}$ & Single ventricle, TGA & $?$ & Caesarean & Epidural & No & Good & $\begin{array}{l}\text { Good: } 38 \text {-week } \\
\text { gestation }(2240 \mathrm{~g})\end{array}$ \\
\hline \multirow[t]{2}{*}{ Present case } & $\begin{array}{l}\text { Single ventricle, I-TGA. ASD, } \\
\text { one AV valve, PS, subvalvular PS }\end{array}$ & 24 & Vaginal & $\begin{array}{l}\text { Pudendal } \\
\text { block and intiltration }\end{array}$ & No & Good & $\begin{array}{l}\text { Good: } 35 \text {-week } \\
\text { gestation }(1740 g)\end{array}$ \\
\hline & & 29 & $\begin{array}{l}\text { Emergency } \\
\text { Caesarean }\end{array}$ & $\begin{array}{l}\text { Epidural for labour, } \\
\text { Caesarean section } \\
\text { \& postop. pain }\end{array}$ & No & Good & $\begin{array}{l}\text { Good; } 36 \text {-week } \\
\text { gestation ( } 1845 \mathrm{~g} \text { ) }\end{array}$ \\
\hline
\end{tabular}

Abbreviations: aortic regurgitation (AR), atrial septal defect (ASD), atrioventricular (AV), patent ductus arteriosus (PDA), pulmonary valve stenosis (PS), levo-transposition of the great areries (I-TGA)

$\mathrm{ml} 3$ per cent 2-chloroprocaine with $1 \mathrm{mEq} \mathrm{NaHO}_{3}$ per 10 $\mathrm{ml}$ 2-chloroprocaine; $300 \mathrm{ml}$ Ringer's lactate was given intravenously. A fifth thoracic $\left(T_{5}\right)$ dermatome level of sensory blockade was achieved with no change in maternal haemodynamic status. The patient was given 100 per cent oxygen via a face mask with no change in her pulse oximetric saturation. The Caesarean section was begun, and a tight nuchal cord was noted at delivery. A $1845 \mathrm{~g}$ male was delivered with Apgar scores of seven and eight at one and five minutes, respectively.

Postpartum, during skin closure, the patient received $100 \mu \mathrm{g}$ fentanyl in $6 \mathrm{ml}$ normal saline through her epidural catheter for postoperative analgesia. When the effects of the 2-chloroprocaine dissipated $15 \mathrm{~min}$ after the end of the Caesarean section, the patient complained of abdominal pain. Therefore, she was given an overnight continuous epidural infusion of 0.125 per cent bupivacaine with 6.25 $\mu \mathrm{g} \cdot \mathrm{ml}^{-1}$ fentanyl at $8 \mathrm{ml} \cdot \mathrm{hr}^{-1}$ which resulted in excellent analgesia and motor function. The next morning the CVP, arterial and epidural catheters were removed without complications. Subcutaneous morphine and heparin were commenced for pain relief and prophylaxis against thromboembolism, respectively. She was discharged from the hospital seven days later with her baby after an uncomplicated postoperative recovery.

\section{Discussion}

Single ventricle anomalies with TGA are rarely seen in parturients. ${ }^{2-9}$ The management of intrapartum anaesthesia in patients with right-to-left shunts should be aimed at providing adequate analgesia while maintaining a favourable balance between systemic and pulmonary vascular resistances and, therefore, blood flow. By minimizing the release of endogenous catecholamines produced by pain and anxiety, adequate analgesia helps to prevent increases in pulmonary vascular resistance. A decreased systemic vascular resistance (SVR) and/or venous return should be avoided because the right-to-left shunt may be increased. Regardless of the anaesthetic technique employed, it is important to maintain adequate venous return in these patients by using intravenous fluids appropriately and avoiding aortocaval compression.

When determining the maternal risk associated with cyanotic heart disease, the presence of pulmonary hypertension is an important factor. Indeed, some investigators have attributed the difference in maternal mortality among Eisenmenger's syndrome (27 per cent), primary pulmonary hypertension (50 per cent) and tetralogy of Fallot (four per cent) to the degree of pulmonary hypertension. ${ }^{12-14}$ In reviewing the cases to date of parturients with single ventricles (Table II), it can be seen that those parturients without pulmonary hypertension have a favourable maternal outcome regardless of the mode of delivery, vaginal versus Caesarean section, or type of anaesthesia, regional versus general.

Unlike previous case reports of parturients with single 
ventricle and TGA, this case report describes the use of lumbar epidural analgesia/anaesthesia with local anaesthetics for labour, emergency Caesarean section and postoperative pain. In preparing the patient for emergency Caesarean section, we were aware that the rapid extension of the epidural anaesthetic to a $\mathrm{T}_{5}$ dermatome level could have led to decreased venous filling and SVR due to increased sympathetic nerve blockade. This could have been detrimental to the balance between pulmonary and systemic blood flow. However, no problem occurred, perhaps because the patient already had a wellcompensated partial sympathetic nerve blockade due to epidural analgesia for labour. If a decrease in blood pressure had occurred with a worsening of her right-to-left shunt, we would have treated her with intravenous fluids and neosynephrine, which has been shown to be safe in pregnant patients. ${ }^{15}$ Overall, the success of our patient's pregnancies probably was due to her normal pulmonary vasculature. Her subvalvular and valvular stenosis may have protected against pulmonary hypertension.

Patients with cyanotic congenital heart disease are at increased risk of developing paradoxical emboli, such as air and thromboemboli. During this pregnancy, our patient developed a retinal artery thromboembolism. Therefore, heparin was commenced and this was discontinued the night before her elective induction. Polycythaemia and the hypercoagulable pregnant state may have contributed to the development of a thromboembolus. ${ }^{16,17}$ The use of regional anaesthesia is controversial in patients who have been on anticoagulant therapy and have abnormal coagulation variables. ${ }^{16}$ In using epidural anaesthetics in these patients, there is the possibility of an epidural haematoma. Therefore, a high degree of suspicion should be maintained to detect early spinal cord compression. ${ }^{11}$ In this case, epidural haematoma formation was unlikely because the patient's coagulation profile was only minimally elevated. The benefit of epidural analgesia/anaesthesia may not only have been excellent analgesia but also, perhaps, a decreased likelihood of postoperative deep venous thrombus formation. Epidural analgesia with local anaesthetics has been shown to decrease the incidence of deep venous thrombosis and pulmonary embolus in certain postoperative patient groups. ${ }^{18}$

This case reports not only a successful pregnancy but also the use of epidural analgesia/anaesthesia for pain relief during labour, emergency Caesarean section and postoperative recovery in a parturient with single ventricle and TGA. Therefore, based on a limited number of case reports, any anaesthetic technique, regional or general, may be employed safely in these patients if pulmonary hypertension is absent. However, there are risks of pregnancy to both mother and fetus which include embolic events, endocarditis, congestive heart failure, dysrrhythmias, anoxia, intrauterine growth retardation and an increased incidence of fetal wastage. ${ }^{3}$ Therefore, in managing these patients a team approach is required with cooperation among obstetricians, cardiologists and anaesthetists.

\section{References}

I Hurst JW, Logue RB, Schlant RC, Sonnenblick EH, Wallace $A G$, Wenger $N K$. The Heart. 6th ed. New York: MCGraw-Hill, Inc., 1985: 703-4.

2 Mandel A, Hirsh V. Cor triloculare biatrialum. Am Heart J 1963; 66: 104-7.

3 Yuzpe AA, Sanghvi VR, Johnson FL, Robinson JG. Successful pregnancy in a patient with single ventricle and other congenital cardiac anomalies. Can Med Assoc J 1970; 103: 1073-5.

4 Seeds JW, Cefalo RC. Pregnancy with congenital heart disease: a two-chambered heart. Am J Obstet Gynecol 1977; 127: 213-4.

5 Ahmad S, Hawes D, Dooley S, Faure E, Brumner $E A$. Intrathecal morphine in a parturient with a single ventricle. Anesthesiology 1981; 54: 515-6.

6 Leibbrandt $G$, Munch $U$, Gander $M$. Two successful pregnancies in a patient with single ventricle and transposition of the great arteries. Int J Cardiol 1982; I: 257-62.

7 Stiller RJ, Vintzileos AM, Nochimson DJ, Clememt D, Campbell $W A$, Leach $C N J r$. Single ventricle in pregnancy: case report and review of the literature. Obstet Gynecol 1984; 64: 18S-20S.

8 Copel JA, Harrison D, Whittemore R, Hobbins JC. Intrathecal morphine analgesia for vaginal delivery in a woman with a single ventricle: a case report. J Reprod Med 1986; 31: 274-6.

9 Baunann H, Schneider H, Drack G, Alon E, Huch $A$. Pregnancy and delivery by Caesarean section in a patient with transposition of the great arteries and single ventricle: case report. Br J Obstet Gynaecol 1987; 94: 704-8.

10 Mangano DT. Anesthesia for the pregnant cardiac patient. In: Shnider SM, Levinson G (Eds.). Anesthesia for Obstetrics. 2nd ed., Baltimore: Williams and Wilkins Co. 1979: 197-200.

11 Bromage PR. Epidural Analgesia. Philadelphia: WB Saunders Co., 1978: 191-5 and 231-2.

12 Gleicher N, Midwall J, Hocberger D, Jaffin H. Eisenmenger's syndrome and pregnancy. Obstet Gynecol Surv 1979; 34: 721-4I.

13 Jones $A M$, Howitt $G$. Eisenmenger's syndrome in pregnancy. Br Med J 1965; 1: 1627-31.

14 Sorensen MB, Korshin JD, Fernandes A, Secher $O$. The use of epidural analgesia for delivery in a patient with 
pulmonary hypertension. Acta Anaesthesiol Scand 1982;

26: 180-2.

15 Ramanathan S, Grant GJ. Vasopressor therapy for hypotension due to epidural anaesthesia for caesarean section. Acta Anaesthessiol Scand 1988. 32; 559-65.

16 Perloff JK, Rosove MH, Child JS, Wright $G B$. Adults with cyanotic congenital heart disease: hematologic management. Ann Intern Med 1988; 109: 406-12.

17 Writer WDR. Hematologic disease. In: James FM, Wheeler AS, Dewan DM (Eds.). Obstetric Anesthesia: The Complicated Patient. 2nd ed. Philadelphia: FA Davis Co., 1988: 296-9.

18 Modig J. Thromboembolism and blood loss: continuous epidural block versus general anesthesia with controlled ventilation. Regional Anesthesia 1982; 7: S84-8. 